\title{
18Fluorine-fluorodeoxyglucose PET/CT Imaging in Childhood Malignancies
}

\author{
Çocukluk Çağı Malignitelerinde ${ }^{18}$ Flor-florodeoksiglukoz PET/BT Görüntüleme
}

\author{
(1) Nilüfer Bıçakçı1, (1) Murat Elli2 \\ IUniversity of Health Sciences Turkey, Samsun Training and Research Hospital, Clinic of Nuclear Medicine, Samsun, Turkey \\ 2Istanbul Medipol University Faculty of Medicine, Department of Pediatric Oncology, Istanbul, Turkey
}

\begin{abstract}
Objectives: The aim of the study was to evaluate the utility of ${ }^{18} \mathrm{fluorine}$-fluorodeoxyglucose $\left({ }^{18} \mathrm{~F}-\mathrm{FDG}\right)$ positron emission tomography/computed tomography (PET/CT) in the diagnosis, staging, restaging, and treatment response of childhood malignancies.

Methods: This study included 52 patients (32 boys, 20 girls) who were referred to our clinic between November 2008 and December 2018 with the diagnosis of malignancy. The patients were evaluated retrospectively. Median age of the patients was 13 years (range 2-17). ${ }^{18} \mathrm{~F}-\mathrm{FDG}$ was given to the patients intravenously, and time of flight with PET/16 slice CT was performed 1 hour thereafter. The lowest dose was $2 \mathrm{mCi}(74 \mathrm{MBq})$ and the highest dose was $10 \mathrm{mCi}(370 \mathrm{MBq})$. Fasting blood sugars of all patients were found below $200 \mathrm{mg} / \mathrm{dL}(11.1 \mathrm{mmol} / \mathrm{L})$.

Results: ${ }^{18} \mathrm{~F}$-FDG PET/CT was performed to evaluate the response to treatment in 38 of 52 children, staging in 11 patients (staging and evaluation of the response to treatment in nine of them), restaging in 2 patients, restaging, and evaluation of the response to treatment in 1 patient. ${ }^{18} \mathrm{~F}-\mathrm{FDG}$ PET/CT examination was reported as normal in 13 patients ( 5 girls, 8 boys). The pathological ${ }^{18} \mathrm{~F}-\mathrm{FDG}$ uptake was detected in 39 patients ( 14 girls, 25 boys), which indicated metastasis and/or recurrence of the primary disease. Total number of deaths was 30 (13 girls, 17 boys).

Conclusion: ${ }^{18} \mathrm{~F}-\mathrm{FDG}$ PET/CT has a significant role for staging, restaging, treatment response, and detection of metastatic disease but it is limited for the early diagnosis of childhood cancers.

Keywords: ${ }^{18} \mathrm{~F}-\mathrm{FDG} \mathrm{PET} / \mathrm{CT}$, childhood malignancy, staging, restaging, response
\end{abstract}

\section{Öz}

Amaç: Çalışmamızın amacı, çocukluk çağı malignitelerinin tanı, evreleme, yeniden evreleme ve tedaviye cevabın değerlendirilmesinde ${ }^{18} f l o r-$ florodeoksiglukoz (18F-FDG) pozitron emisyon tomografisi/bilgisayarlı tomografinin (PET/BT) yararını göstermektir.

Yöntem: Kasım 2008 ve Aralık 2018 tarihleri arasında, malignensi tanıı 52 hastanın (32 erkek, 20 kız) dosyaları ve görüntüleri geriye dönük olarak incelendi. Ortalama yaş 13 (2-17) idi. ${ }^{18} \mathrm{~F}-F D G '$ in intravenöz enjeksiyonundan 1 saat sonra, time of flight/16 kesit BT yapıldı. Çalışmamızda en düşük doz 2 mCi (74 MBq), en yüksek doz 10 mCi (370 MBq). Tüm hastaların açık kan şekerleri 200 mg/dL'nin (11,1 mmol/L) altındaydı.

Bulgular: ${ }^{18} \mathrm{~F}-\mathrm{FDG}$ PET/BT, 52 hastanın 38'ine tedaviye yanıt değerlendirilmesi, 11 hastaya evreleme ( 9 hasta evreleme ve aynı zamanda tedaviye yanıt değerlendirilmesi), 2 hastaya yeniden evreleme, 1 hastaya yeniden evreleme ve tedaviye yanıt değerlendirilmesi amacıyla yapıldı. ${ }^{18} \mathrm{~F}$-FDG PET/ BT çalışması 13 hastada ( 5 kız, 8 erkek) normaldi. Otuz dokuz hastada (14 kız, 25 erkek) çalışma, metastaz ve/veya primer hastalığın nüksü ile uyumlu bulundu. Toplam ölüm sayısı 30 (13 kı, 17 erkek) idi.

Sonuç: ${ }^{18} \mathrm{~F}-\mathrm{FDG}$ PET/BT çocukluk çağı malignensilerinin tanı, evreleme, yeniden evreleme ve tedaviye yanıt değerlendirilmesi açısından çok faydalıdır ancak erken tanıda yararı sinırıdır.

Anahtar kelimeler: ${ }^{18} \mathrm{~F}-\mathrm{FDG}$ PET/BT, çocukluk çağı maligniteleri, evreleme, yeniden evreleme, tedaviye yanıt

Address for Correspondence: Nilüfer Bıçakçı MD, University of Health Sciences Turkey, Samsun Training and Research Hospital,

Clinic of Nuclear Medicine, Samsun, Turkey

Phone: +90 3623111500 E-mail: niluferbicakci@gmail.com ORCID ID: orcid.org/0000-0003-4124-1225

Received: 08.08.2020 Accepted: 13.10.2020

${ }^{\circ}$ Copyright 2021 by Turkish Society of Nuclear Medicine

Molecular Imaging and Radionuclide Therapy published by Galenos Yayınevi. 


\section{Introduction}

${ }^{18}$ Fluorine-fluorodeoxyglucose ( ${ }^{18} \mathrm{~F}-\mathrm{FDG}$ ) positron emission tomography/computed tomography (PET/CT) plays an important role for diagnosis, staging, restaging, response to treatment, and evaluation of prognosis in childhood malignancies $(1,2)$. PET-only examinations have been replaced by hybrid systems in the recent decades, where PET and $\mathrm{CT}$ are used together in oncology (3). In this imaging system, PET and CT are used together for functional data and morphological information, respectively (4). ${ }^{18} \mathrm{~F}-\mathrm{FDG}$ $\mathrm{PET} / \mathrm{CT}$ is also known to have high sensitivity and specificity $(86 \%$ and $80 \%$, respectively) in childhood malignancies $(5,6,7)$.

The type of childhood malignancies varies according to the age groups. The most common childhood malignancy is leukemia with a rate of $30 \%$; other malignancies are brain tumors $(20 \%)$, lymphomas (14\%), neuroblastoma $(7 \%)$, soft tissue sarcomas (7\%), Wilms' tumor (6\%), bone tumors (5\%), germ cell tumors (3\%), melanoma $(3 \%)$, hepatic tumors (1\%), etc. Lymphoma and germ cell tumors are more common in children between the ages of 14 and 19 years $(8,9,10,11,12,13,14)$. The childhood tumors in which ${ }^{18} \mathrm{~F}-\mathrm{FDG}$ PET/CT is used frequently include lymphomas, brain tumors, soft tissue sarcomas, neuroblastoma, Wilms' tumor, germ cell tumors, and neurofibromatosis 1 (15). The most commonly used radionuclides in nuclear medicine for the cancer imaging are gallium-67 $\left({ }^{67} \mathrm{Ga}\right)$ citrate, thallium-201 chloride, technetium-99m sestamibi, and ${ }^{18} \mathrm{~F}-\mathrm{FDG}$. ${ }^{18} \mathrm{~F}-\mathrm{FDG}$ causes lower radiation exposure due to relatively short half-life (110 minutes), and it is also a widely available radionuclide agent (2). ${ }^{18} \mathrm{~F}-\mathrm{FDG}$ mimics glucose in cell uptake process and thus acts as a marker of glucose usage. ${ }^{18} \mathrm{~F}-\mathrm{FDG}$ is not a tumor-specific agent and can be kept in cells in case of many physiological and pathological conditions. Dualtime-point imaging can help to increase the specificity of ${ }^{18}$ F-FDG imaging (3).

We evaluated the role of ${ }^{18} \mathrm{~F}-\mathrm{FDG}$ PET/CT in diagnosis, staging, restaging, treatment response, and detection of metastatic disease of childhood malignancies in this study.

\section{Materials and Methods}

Fifty-two children (32 boys, 20 girls) with tissue-confirmed malignancies underwent ${ }^{18} \mathrm{~F}-\mathrm{FDG}$ PET/CT examination between November 2008 and December 2018. The median age of the patients was 13 years (range 2-17 years). The study was approved by the University of Health Sciences Turkey, Samsun Training and Research Hospital of Local Ethics Committee (protocol number: GOKA/2020/10/6).
All imaging studies were performed under at least 4 hours of total fasting. The dose of ${ }^{18} \mathrm{~F}-\mathrm{FDG}$ was calculated as $0.15 \mathrm{mCi} / \mathrm{kg}(5.55 \mathrm{MBq} / \mathrm{kg})$ between 2008 and 2010. After 2010, it was calculated according to the radiopharmaceutical doses published in the 2016 North American Consensus Guidelines, which has been updated as the whole-body ${ }^{18} \mathrm{~F}-\mathrm{FDG}$ with $3.7-5.2 \mathrm{MBq} / \mathrm{kg}(0.1-0.4$ $\mathrm{mCi} / \mathrm{kg})$, and the minimum dose was recommended as 37 $\mathrm{MBq}(1 \mathrm{mCi})$. In our study, the lowest dose was $2 \mathrm{mCi}$ (74 MBq), and the highest dose was $10 \mathrm{mCi}(370 \mathrm{MBq}$ ). Fasting blood sugar level of all patients was found to be less than $200 \mathrm{mg} / \mathrm{dL}(11.1 \mathrm{mmol} / \mathrm{L})$. CT parameters were obtained with ultra-low dose $(80 \mathrm{kVp}, 5 \mathrm{mAs}$, and 1.5:1 pitch). After $45-60$ minutes from application of ${ }^{18} \mathrm{~F}-\mathrm{FDG}, \mathrm{CT}$ images were obtained for attenuation correction without intravenous contrast, and then PET images were gathered. ${ }^{18} \mathrm{~F}-\mathrm{FDG}$ examination was performed with time of flight PET/16 section CT (Philips Gemini TF), and the PET detector crystal material was LYSO.

Sedation was used in 6 patients who were under 8 years of age during the ${ }^{18} \mathrm{~F}-\mathrm{FDG}$ PET/CT examination. We used the oral chloral hydrate as $50-70 \mathrm{mg} / \mathrm{kg}$ for young children less than $15 \mathrm{~kg}$ of body weight, according to application guide of the American Academy of Pediatrics $(16,17)$. This dosage is appropriate in most nuclear medicine applications. In our study it was sufficient for the younger age group.

Brown adipose tissue produces heat in case of exposure to cold and causes focal increased ${ }^{18} \mathrm{~F}-\mathrm{FDG}$ uptake and may mimic muscle or malignancy $(18,19,20)$. However, diazepam was not used in any of our patients as the waiting room temperatures were ensured to be high enough to prevent cold exposure in our clinic.

${ }^{18} \mathrm{~F}-\mathrm{FDG}$ PET/CT indications and findings of the patients were analyzed retrospectively. Patient characteristics are listed in Table 1.

No statistical analysis was performed.

\section{Results}

${ }^{18} \mathrm{~F}-\mathrm{FDG}$ PET/CT was applied to 52 children for evaluation of response to treatment in 38, staging in 11 (2 staging and nine staging and evaluating response to treatment), restaging in 2, evaluation of response to treatment with restaging in 1 patient.

Twenty-three patients had the diagnosis of lymphoma [14 non-Hodgkin's lymphoma (NHL), $9 \mathrm{HL}$ ], and ${ }^{18} \mathrm{~F}-\mathrm{FDG}$ PET/ $\mathrm{CT}$ was performed for staging and response to treatment in 10 , for response to treatment in 11 , and for restaging in 2 patients. ${ }^{18} \mathrm{~F}-\mathrm{FDG} \mathrm{PET} / \mathrm{CT}$ detected more nodal lesions than $\mathrm{CT}$ in 10 staged patients. Detection of multiple lesions 


\begin{tabular}{|c|c|c|c|c|}
\hline Age & Gender & Diagnosis & Site of primary tumor & PET indication \\
\hline 16 & M & Ewing's sarcoma & Right fibula & Therapy response assessment \\
\hline 12 & M & Neuroblastoma & Left adrenal gland & Therapy response assessment \\
\hline 16 & M & $\begin{array}{l}\text { Rhabdomyosarcoma (Li-Fraumeni } \\
\text { syndrome) }\end{array}$ & Right inguinal mass & Therapy response assessment \\
\hline 8 & M & Nasopharyngeal cancer & Right posterior wall of the nasopharynx & Therapy response assessment \\
\hline 9 & M & Rhabdomyosarcoma & Retroperitoneal mass & Therapy response assessment \\
\hline 11 & M & $\mathrm{NHL}$ & Abdominal lymphadenopathy & Therapy response assessment \\
\hline 16 & $\mathrm{~F}$ & Ewing's sarcoma & Right femur & Therapy response assessment \\
\hline 7 & $\mathrm{~F}$ & Neuroblastoma & Left adrenal gland & Therapy response assessment \\
\hline 11 & $\mathrm{~F}$ & $\mathrm{NHL}$ & Cervical and mediastinal lymphadenopathy & Therapy response assessment \\
\hline 5 & $\mathrm{~F}$ & Immature teratoma & Left adnexa & Staging \\
\hline 4 & $\mathrm{~F}$ & Retinoblastoma & Right eye & Therapy response assessment \\
\hline 9 & M & $\mathrm{HL}$ & Mediastinal and axillary lymphadenopathy & Therapy response assessment \\
\hline 14 & $\mathrm{~F}$ & Malign mesenchymal tumor & $\begin{array}{l}\text { Anterior projection of the right sacroiliac } \\
\text { joint }\end{array}$ & Therapy response assessment \\
\hline 14 & M & $\mathrm{NHL}$ & Cervical lymphadenopathy & Therapy response assessment \\
\hline 16 & M & $\mathrm{NHL}$ & Cervical lymphadenopathy & Therapy response assessment \\
\hline 17 & M & $\mathrm{HL}$ & Mediastinal and axillary lymphadenopathy & Staging \\
\hline 17 & M & Ewing's sarcoma & Left femur & Therapy response assessment \\
\hline 9 & M & Rhabdomyosarcoma & Left inguinal mass & Therapy response assessment \\
\hline 15 & M & Neuroblastoma & Right adrenal gland & Therapy response assessment \\
\hline 15 & M & Ewing's sarcoma & Left tibia & Therapy response assessment \\
\hline 2 & $\mathrm{~F}$ & $\mathrm{NHL}$ & $\begin{array}{l}\text { Mediastinal, axillar, abdominal } \\
\text { lymphadenopathy }\end{array}$ & Therapy response assessment \\
\hline 14 & M & $H L$ & Cervical and mediastinal lymphadenopathy & Therapy response assessment \\
\hline 17 & $\mathrm{~F}$ & $\mathrm{HL}$ & Cervical lymphadenopathy & Therapy response assessment \\
\hline 5 & $\mathrm{~F}$ & Germ cell tumor & Left adnexal mass & Therapy response assessment \\
\hline 13 & $\mathrm{~F}$ & Malignant melanoma & Back skin & Therapy response assessment \\
\hline 9 & $\mathrm{~F}$ & Neuroblastoma & Abdominal mass & Therapy response assessment \\
\hline 14 & $\mathrm{~F}$ & Malign mesenchymal tumor & Posterior segment of the S1-2 & Therapy response assessment \\
\hline 7 & $\mathrm{~F}$ & Neuroblastoma & Abdominal mass & Therapy response assessment \\
\hline 15 & M & Testicular cancer & Right testicle & Therapy response assessment \\
\hline 14 & $\mathrm{~F}$ & Malignant mesenchymal tumor & Posterior segment of the sacrum & Therapy response assessment \\
\hline 14 & M & Ewing's sarcoma & Right tibia & Therapy response assessment \\
\hline 17 & $\mathrm{~F}$ & Ewing's sarcoma & Sol femur & Staging \\
\hline 4 & M & Neuroblastoma & Abdominal mass & Therapy response assessment \\
\hline 13 & $\mathrm{~F}$ & Rhabdomyosarcoma & Left inguinal mass & Therapy response assessment \\
\hline 17 & M & Testicular cancer & Left testicle & $\begin{array}{l}\text { Therapy response assessment } \\
\text { and restaging }\end{array}$ \\
\hline 5 & M & Neuroblastoma & Abdominal mass & Therapy response assessment \\
\hline 13 & M & $\mathrm{HL}$ & $\begin{array}{l}\text { Mediastinal, axillar, abdominal } \\
\text { lymphadenopathy }\end{array}$ & Therapy response assessment \\
\hline
\end{tabular}




\begin{tabular}{|c|c|c|c|c|}
\hline Age & Gender & Diagnosis & Site of primary tumor & PET indication \\
\hline 14 & $\mathrm{~F}$ & NHL (Burkitt's lymphoma) & Cervical lymphadenopathy & Therapy response assessment \\
\hline 11 & M & $\begin{array}{l}\text { Peripheral primitive neuroectodermal } \\
\text { tumor }\end{array}$ & Left posterior mediastinum & Therapy response assessment \\
\hline 8 & $\mathrm{~F}$ & Ewing's sarcoma & Right femur & Therapy response assessment \\
\hline 15 & M & NHL (Burkitt's lymphoma) & $\begin{array}{l}\text { Mediastinal, abdominal, and pelvic } \\
\text { lymphadenopathy }\end{array}$ & $\begin{array}{l}\text { Staging and therapy response } \\
\text { assessment }\end{array}$ \\
\hline 15 & M & $\mathrm{NHL}$ & Abdominal lymphadenopathy & $\begin{array}{l}\text { Staging and therapy response } \\
\text { assessment }\end{array}$ \\
\hline 14 & M & $\mathrm{NHL}$ & Abdominal lymphadenopathy & $\begin{array}{l}\text { Staging and therapy response } \\
\text { assessment }\end{array}$ \\
\hline 14 & M & $\mathrm{NHL}$ & Abdominal and pelvic lymphadenopathy & $\begin{array}{l}\text { Staging and therapy response } \\
\text { assessment }\end{array}$ \\
\hline 16 & M & $\mathrm{HL}$ & Cervical lymphadenopathy & $\begin{array}{l}\text { Staging and therapy response } \\
\text { assessment }\end{array}$ \\
\hline 15 & M & $\mathrm{HL}$ & Cervical and mediastinal lymphadenopathy & $\begin{array}{l}\text { Staging and therapy response } \\
\text { assessment }\end{array}$ \\
\hline 13 & $\mathrm{~F}$ & $\mathrm{NHL}$ & Abdominal lymphadenopathy & $\begin{array}{l}\text { Staging and therapy response } \\
\text { assessment }\end{array}$ \\
\hline 11 & $\mathrm{~F}$ & $\mathrm{NHL}$ & Abdominal and pelvic lymphadenopathy & Restaging \\
\hline 16 & M & $\mathrm{HL}$ & Cervical lymphadenopathy & Restaging \\
\hline 15 & M & $\mathrm{HL}$ & Cervical lymphadenopathy & Therapy response assessment \\
\hline 12 & M & $\mathrm{NHL}$ & $\begin{array}{l}\text { Mediastinal, axillar, abdominal } \\
\text { lymphadenopathy }\end{array}$ & $\begin{array}{l}\text { Staging and therapy response } \\
\text { assessment }\end{array}$ \\
\hline 11 & M & $\mathrm{NHL}$ & Abdominal lymphadenopathy & $\begin{array}{l}\text { Staging and therapy response } \\
\text { assessment }\end{array}$ \\
\hline
\end{tabular}

in the skeletal system and bone marrow increased the stage in these patients (Figure 1).

Patients with Ewing's sarcoma (ES), rhabdomyosarcoma, neuroblastoma, malignant melanoma, malignant mesenchymal tumor, retinoblastoma, nasopharynx carcinoma, and germ cell tumors did not undergo ${ }^{18} \mathrm{~F}-\mathrm{FDG}$ PET/CT study before treatment, and ${ }^{18} \mathrm{~F}-\mathrm{FDG}$ PET/CT was performed after treatment to evaluate the response to treatment. Metastatic disease was detected by ${ }^{18}$ F-FDG PET/ $\mathrm{CT}$ in the bone, liver, brain, and abdominal and mediastinal lymph nodes of the patients with neuroblastoma $(n=7)$ during follow-up.

Seven patients with ES and one with peripheric primitive neuroendocrine tumor were evaluated with ${ }^{18} \mathrm{~F}-\mathrm{FDG} \mathrm{PET} /$ $\mathrm{CT}$ for local and systemic involvement after chemotherapy. Three local recurrences and five abdominal/inguinal metastatic lymph nodes were detected with the ${ }^{18} \mathrm{~F}-\mathrm{FDG}$ $\mathrm{PET} / \mathrm{CT}$. In patients with rhabdomyosarcoma, ${ }^{18} \mathrm{~F}-\mathrm{FDG} \mathrm{PET} /$ $\mathrm{CT}$ detected three recurrent diseases and one metastatic disease on follow-up after adjuvant therapy (one had LiFraumeni syndrome).

${ }^{18}$ F-FDG PET/CT was performed for evaluation of treatment response in 2 patients with testicular carcinoma. In the other patient, ${ }^{18} \mathrm{~F}-\mathrm{FDG} \mathrm{PET} / \mathrm{CT}$ was performed for restaging, and a lung metastasis was detected (Figure 2).

No recurrence or metastasis was identified in ${ }^{18} \mathrm{~F}-\mathrm{FDG}$ PET/CT of 13 patients. Thirty patients died on follow-up; 7 patients had $\mathrm{NHL}$, and the other 23 patients had ES $(n=8)$, neuroblastoma $(n=7)$, rhabdomyosarcoma $(n=1)$, malignant mesenchymal tumor $(n=1)$, germ cell tumor $(n=1)$, immature teratoma $(n=1)$, and retinoblastoma $(n=1)$ (Table 2).

\section{Discussion}

Our findings indicate that ${ }^{18} \mathrm{~F}-\mathrm{FDG}$ PET/CT is an essential imaging modality and provided important information for diagnosis, staging, restaging, evaluation of the response to treatment, and detection of metastatic disease. However, 
this study is limited in early diagnosis of childhood malignancies.

Although childhood malignancies are relatively rare as compared to adults, still they are a significant cause of mortality and constitute the second most frequent cause of death after trauma in children (21). Leukemia accounts for more than half of all childhood solid tumors, and the other frequent childhood cancers are brain tumors, lymphomas, neuroblastoma, soft tissue sarcomas, Wilms' tumor, and bone tumors $(8,21)$.

Childhood cancers differ from adults in terms of epidemiology, histological patterns, clinical behavior,

Table 2. Cancer types, numbers, and follow-up results of all patients

\begin{tabular}{|l|l|l|l|l|}
\hline \multirow{2}{*}{ Diagnosis } & PET/CT results & \multirow{2}{*}{ Ex (n=30) } \\
\cline { 2 - 5 } & Normal & Recurrence & Metastasis & \\
\hline Non-Hodgkin's lymphoma $(n=14)$ & 5 & 9 & 0 & 7 \\
\hline Hodgkin's lymphoma $(n=9)$ & 5 & 4 & 0 & 0 \\
\hline Ewing's sarcoma $(n=8)$ & 0 & 3 & 5 & 8 \\
\hline Rhabdomyosarcoma $(n=4)$ & 0 & 3 & 1 & 4 \\
\hline Neuroblastoma $(n=7)$ & 0 & 0 & 7 & 7 \\
\hline Malignant mesenchymal tumor $(n=3)$ & 1 & 0 & 1 & 1 \\
\hline Testicular cancer $(n=2)$ & 1 & 0 & 0 & 0 \\
\hline Retinoblastoma $(n=1)$ & 0 & 1 & 1 & 1 \\
\hline Immature teratoma (n=1) & 0 & 0 & 0 & 1 \\
\hline Malignant melanoma $(n=1)$ & 0 & 0 & 1 & 0 \\
\hline Nasopharyngeal tumor $(n=1)$ & 1 & 0 & & 0 \\
\hline Germ cell tumor $(n=1)$ & 0 & 0 & & 1 \\
\hline PET: Positron emission tomography, CT: Computed tomography & & & \\
\hline
\end{tabular}

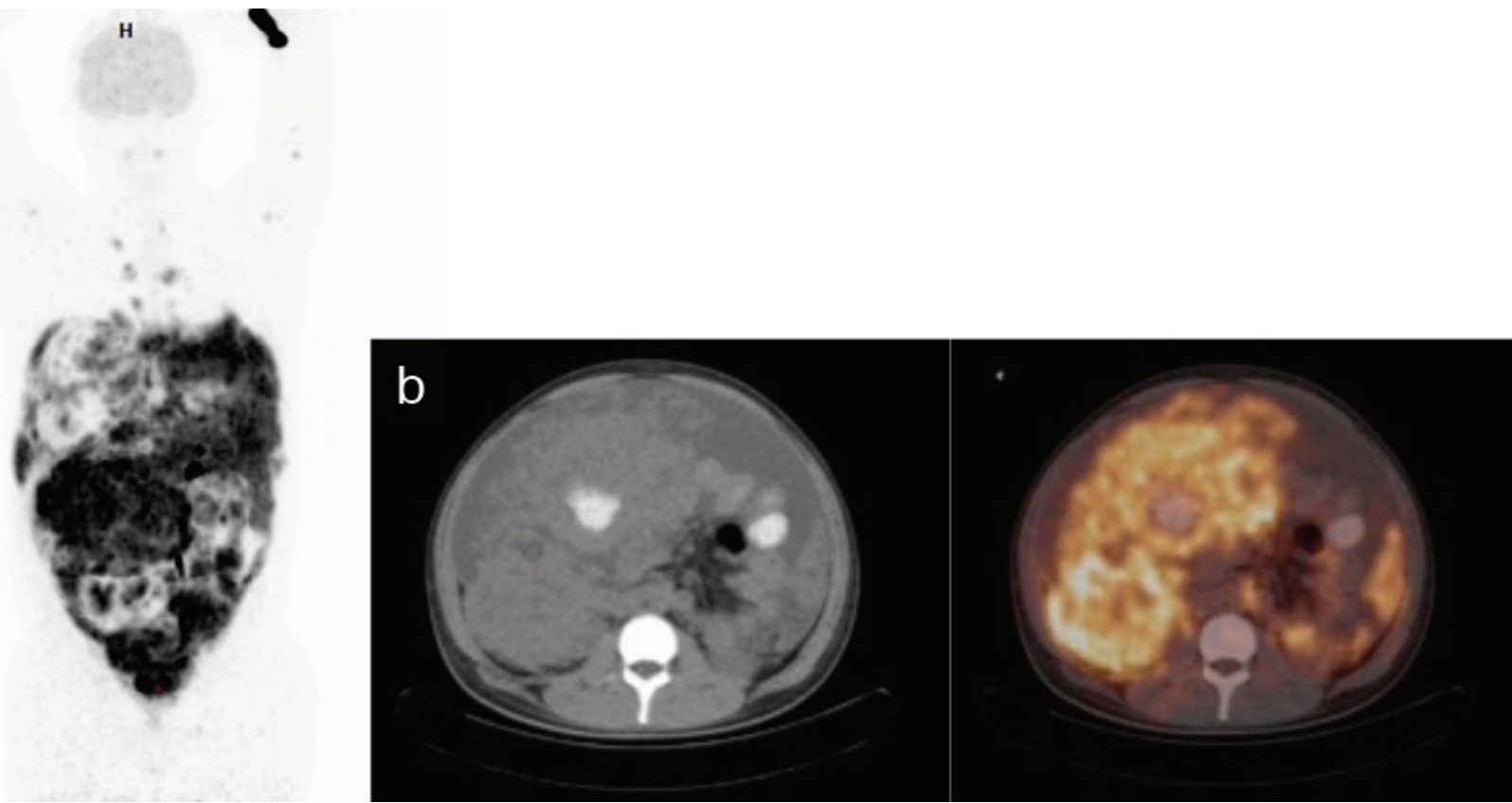

Figure 1. MIP (a), transaxial CT (b), and fusion 18F-FDG PET/CT images of a 15-year-old male patient. Abdominal lymph node biopsy revealed a highgrade malign B-cell lymphoma (Burkitt's lymphoma). Multiple hypermetabolic mediastinal, abdominal, pelvic lymph nodes, massive abdominal fluid, and bone marrow involvement were seen on 18F-FDG PET/CT imaging

${ }^{18 F-F D G: ~}{ }^{18}$ Fluorine-fluorodeoxyglucose, PET: Positron emission tomography, CT: Computed tomography, MIP: Maximum intensity projection 
treatment response, and prognosis. Appropriate treatment reduces the mortality rate. Early and correct diagnosis is essential. Improved oncological results lead to an increased incidence of late complications of childhood cancers. ${ }^{18} \mathrm{~F}-\mathrm{FDG}$ $\mathrm{PET} / \mathrm{CT}$ as an imaging technique is well studied in adults. ${ }^{18}$ F-FDG PET/CT is increasingly used for staging, prognosis, determination of biopsy location, evaluation of treatment response, radiotherapy planning, and follow-up in many types of childhood cancers $(5,22,23,24,25,26,27,28)$. The role of ${ }^{18} \mathrm{~F}-\mathrm{FDG} \mathrm{PET} / \mathrm{CT}$ is, however, limited for the early diagnosis of childhood cancers but has a significant role for staging, treatment response, and detection of metastatic disease. Thus, ${ }^{18} \mathrm{~F}-\mathrm{FDG}$ PET/CT has been used increasingly in children with malignancy for these features.

${ }^{18} \mathrm{~F}-\mathrm{FDG}$ is the most commonly used radiopharmaceutical in PET for oncological purposes. ${ }^{18} \mathrm{~F}$-FDG is a cyclotron radiopharmaceutical with a half-life of 110 minutes. ${ }^{18} \mathrm{~F}-\mathrm{FDG}$ is a glucose analog and is transported into the cell by glucose transporters and often participates in the first stage of the physiological glycolytic pathway. Therefore, the degree of ${ }^{18} \mathrm{~F}-\mathrm{FDG}$ uptake indicates the metabolic activity of the cells (29). Evaluation after treatment with therapeutic agents does not affect tumor size immediately but inhibits tumor metabolism and proliferation. So, accumulation of ${ }^{18} \mathrm{~F}-\mathrm{FDG}$ in metabolically active tumor cells has revolutionized oncological imaging. Although this discovery was made several decades ago, the ability of ${ }^{18}$ F-FDG PET imaging for differentiation of active/stable disease and to provide more clinical information than the simple anatomical localization of the disease has been appreciated recently.

New generation PET devices are faster and have higher resolution. ${ }^{18} \mathrm{~F}$-FDG PET reflects both the metabolic status and the proliferative potential of the disease in patients receiving either conventional or experimental therapy. ${ }^{18} \mathrm{~F}-\mathrm{FDG}$ PET can be used in the majority of childhood cancers as convenient as $\mathrm{CT}$ and magnetic resonance imaging (MRI) $(30,31,32,33)$. Metabolic changes induced by chemotherapy occur before morphological changes. Since the ${ }^{18} \mathrm{~F}-\mathrm{FDG}$ intake provides direct measurement of tumor glucose metabolism, the tumor's response to treatment can be evaluated earlier before the tumor shrinks. The response to treatment may also be predicted more accurately than conventional techniques $(34,35,36,37)$. In our study, we also used ${ }^{18} \mathrm{~F}-\mathrm{FDG}$ as imaging radiopharmaceutical in all pediatric patients. We adjusted the radiopharmaceutical doses in children in line with the 2016 North American Consensus Guidelines renewed in 2010 and later $(38,39)$.

Lymphomas are the third most common type of tumor in the childhood group that account for $14 \%$ of all cancer cases. While NHL is more commonly found in young children, $\mathrm{HL}$ is more common in the adolescent group. ${ }^{18} \mathrm{~F}-\mathrm{FDG} \mathrm{PET} /$ $\mathrm{CT}$ is used for staging, evaluation of treatment response, and relapse of disease, before bone marrow or stem cell

a
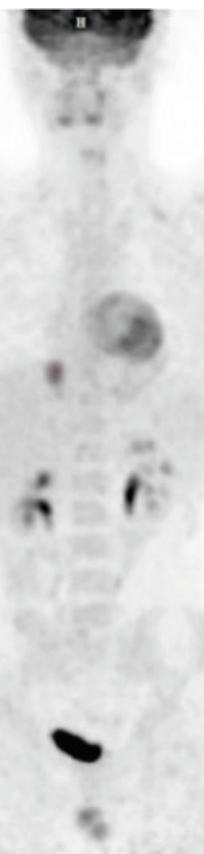

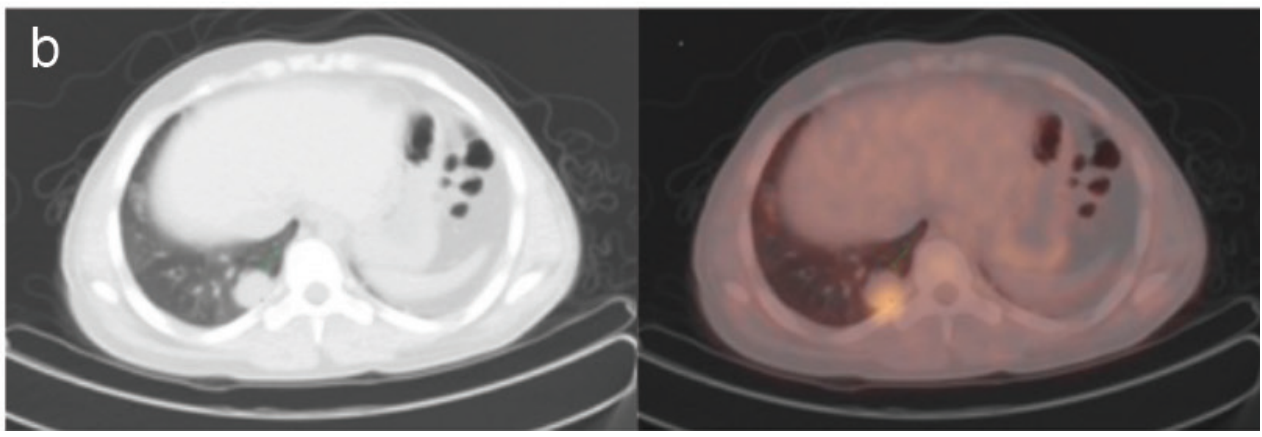

Figure 2. MIP (a), transaxial CT (b), and fusion 18F-FDG PET/CT images of a 16-year-old male patient. Histopathologically, diagnosis was rhabdomyosarcoma. Hypermetabolic metastatic nodule was seen in the right lung posterobasal segment on ${ }^{18 F-F D G ~ P E T / C T ~ i m a g i n g ~}$

18F-FDG: ${ }^{18 F l u o r i n e-f l u o r o d e o x y g l u c o s e, ~ P E T: ~ P o s i t r o n ~ e m i s s i o n ~ t o m o g r a p h y, ~ C T: ~ C o m p u t e d ~ t o m o g r a p h y, ~ M I P: ~ M a x i m u m ~ i n t e n s i t y ~ p r o j e c t i o n ~}$ 
transplantation for diagnostic and prognostic information in children (40). London et al. (41) in their study compared conventional imaging methods ( $\mathrm{CT}$, ultrasonography, MRI, and bone scintigraphy) with ${ }^{18} \mathrm{~F}-\mathrm{FDG}$ PET/CT in pediatric patients diagnosed with $\mathrm{HL}$ and $\mathrm{NHL}$ to differentiate malignant lesion and to predict poor response to treatment. The sensitivity, specificity, and accuracy (95.9\%, 99.7\%, and $99.6 \%$, respectively) of ${ }^{18} \mathrm{~F}-\mathrm{FDG} \mathrm{PET} / \mathrm{CT}$ were found to be higher than other conventional imaging methods (70.1\%, 99.0\%, and $98.3 \%$, respectively) for lymphoma in children. In a study by Cheng et al. (6), ${ }^{18} \mathrm{~F}-\mathrm{FDG}$ PET/ $\mathrm{CT}$ detected lesions that could not be detected by $\mathrm{CT}$ in $50 \%$ of children with $\mathrm{HL}$ and $42.9 \%$ of children with NHL. In our study ${ }^{18} \mathrm{~F}-\mathrm{FDG}$ PET/CT detected more nodal lesions than $\mathrm{CT}$ in 10 patients (50\% of children with $\mathrm{HL}$ and $50 \%$ of children with $\mathrm{NHL}$ ). The stage of malignancy was also increased because of additional lesions in the skeletal system and bone marrow in these patients.

Tumors of sympathetic nervous system constitute about $7 \%$ of all childhood tumors, and neuroblastoma is the most common tumor in this group (42). Approximately $10 \%$ of neuroblastomas do not uptake metaiodobenzylguanidine (MIBG), and ${ }^{18} \mathrm{~F}-\mathrm{FDG}$ PET/CT can be used in the evaluation of MIBG-negative patients $(42,43,44)$. Another study reported that MIBG scintigraphy and ${ }^{18} \mathrm{~F}-\mathrm{FDG}$ PET/CT were equally effective for patients with distant disease in demonstrating bone metastases after primary tumor resection and chemotherapy (45). Choi et al. (46) showed that ${ }^{18} \mathrm{~F}$-FDG PET/CT is more sensitive than CT for evaluation of distant lymph node metastases and can detect recurrent lymph node metastases. Similarly, bone, liver, brain, and widespread lymph node metastases in the abdomen and mediastinum were detected by ${ }^{18} \mathrm{~F}$-FDG PET/ $\mathrm{CT}$ in our patients with neuroblastoma after the adjuvant therapy. Other alternative diagnostic imaging technique in neuroblastoma without MIBG uptake has been investigated including radiolabeled somatostatin analogs such as octreotide and DOTA-conjugated peptides [e.g., ${ }^{68} \mathrm{Ga}$ DOTATATE (DOTA0-Try3) octreotate], ${ }^{68} \mathrm{Ga}$ DOTATOC (DOTA0-Try3) octreotide, and ${ }^{68} \mathrm{Ga}$ DATANOC (DOTA0$1 \mathrm{Nal} 3)$ octreotide. These analogs can bind selectively to somatostatin receptors 2 (47). DOTA-peptides can also be labeled with beta-emitting isotopes, for example, ${ }^{177} \mathrm{Lu}$ or ${ }^{90} \mathrm{Y}$, to provide peptide receptor radionuclide therapy for neuroendocrine tumors in adults $(48,49,50,51,52,53,54)$ and have been used in small studies with relapsed neuroblastoma in children $(55,56,57,58)$.

ES is a heterogenous tumor including ES of the bone, extraosseous ES, and peripheral primitive neuroectodermal tumor. It is the second most common bone malignancy in the pediatric age group, and its incidence among all childhood cancers is approximately 3\% (59). Like many other malignant tumors, ES has an increased glycolysis rate, and as a result, it shows increased ${ }^{18} \mathrm{~F}-\mathrm{FDG}$ accumulation. ${ }^{18} \mathrm{~F}-\mathrm{FDG} \mathrm{PET} / \mathrm{CT}$ is particularly useful in detecting, staging, and restaging of the bone metastases in musculoskeletal tumors and often provides important additional information that may alter the treatment plan (60). Seven patients with ES and one patient with peripheral primitive neuroectodermal tumor were evaluated with ${ }^{18} \mathrm{~F}-\mathrm{FDG}$ PET/ CT for local and systemic disease after chemotherapy in our study. Three local recurrences and five abdominal/ inguinal metastatic lymph nodes were detected with the ${ }^{18}$ F-FDG PET/CT.

Rhabdomyosarcoma is responsible for $4 \%-8 \%$ of malignant diseases in children under 15 years of age (2). Although most of the cases are sporadic, some related congenital and genetic diseases are reported (61). One of our four rhabdomyosarcoma patients had Li-Fraumeni syndrome. ${ }^{18} \mathrm{~F}-\mathrm{FDG} \mathrm{PET} / \mathrm{CT}$ detected three recurrent and one metastatic disease on follow-up after treatment of rhabdomyosarcoma. There are few studies in the literature on the role of ${ }^{18} \mathrm{~F}-\mathrm{FDG}$ PET/CT in treatment response evaluation in childhood rhabdomyosarcoma. Eugene et al. (62) reported that ${ }^{18}$ F-FDG PET/CT predicted the treatment response better than conventional imaging methods in a study group of 23 patients after 3 cycles of treatment. They also had demonstrated $69 \%$ complete radiological response with ${ }^{18} \mathrm{~F}-\mathrm{FDG} \mathrm{PET} / \mathrm{CT}$ while it was reported as $8 \%$ in conventional methods. This finding supports that the metabolic response of the treatment occurred earlier than the response in tumor size. ${ }^{18} \mathrm{~F}-\mathrm{FDG}$ $\mathrm{PET} / \mathrm{CT}$ was also performed in our clinic for evaluating response to treatment in patients with malignant mesenchymal tumor, testicular tumors, retinoblastoma, immature teratoma, nasopharyngeal cancers, and germ cell tumors. ${ }^{18} \mathrm{~F}-\mathrm{FDG} \mathrm{PET} / \mathrm{CT}$ guided the treatment in these patients by evaluating the local recurrence and metastatic disease.

${ }^{18} \mathrm{~F}-\mathrm{FDG}$ PET/CT detected more nodal lesions than $\mathrm{CT}$ in 10 staged patients in our study. ${ }^{18} \mathrm{~F}-\mathrm{FDG}$ PET/CT also increased the stage in these patients by detecting multiple lesions in the skeletal system and bone marrow. So, it has been confirmed that ${ }^{18} \mathrm{~F}-\mathrm{FDG}$ PET/CT has addictive effects on the outcomes and the prognosis of patients.

Despite the above-mentioned beneficial roles of ${ }^{18} \mathrm{~F}-\mathrm{FDG}$ $\mathrm{PET} / \mathrm{CT}$ in malignancy, it has some limitations. Level of radiation dose is a severe problem in children. Lack of simultaneous data acquisition causes image artifacts because of patient movement. Another drawback is 
that CT provides only limited soft tissue contrast. These problems could be overcome by integrating the PET detectors into MR scanner. Dose reductions of up to $73 \%$ have been reported when performing PET/MRI instead of ${ }^{18} \mathrm{~F}-\mathrm{FDG}$ PET/CT because of lack of the CT component, and decreasing the amount of PET tracer administered (because of longer imaging times in PET/MRI) could further reduce the radiation dose (63). Other advantage of PET/MRI is improved soft tissue contrast. Improved soft tissue contrast of MRI leads to improved localization of PET tracer uptake (64). Although ${ }^{18} \mathrm{~F}-\mathrm{FDG} \mathrm{PET} / \mathrm{CT}$ remains the mainstay for functional imaging of oncologic and neurologic processes in children, early experience shows that PET/MRI has great potential in diagnostic algorithms of several pediatric diseases.

The acquisition parameters for the CT portion of the scan should be tailored to the patient's size. CT parameters were obtained with ultra-low dose (80 kVp, $5 \mathrm{mAs}$, and 1.5:1 pitch) in our study. Decreasing the absorbed radiation dose without compromising the image quality can be provided by reducing milliamperes proportionately. This modification results in lower exposed radiation dose in ${ }^{18} \mathrm{~F}-\mathrm{FDG}$ PET/CT than the diagnostic CT. Combination of ${ }^{18} \mathrm{~F}-\mathrm{FDG}$ PET/CT and diagnostic CT has been reported to be used in the literature to prevent doubled radiation exposure to the patient (65). The follow-up of the patients can be performed reliably with ${ }^{18} \mathrm{~F}$-FDG PET/CT in order to further reduce the radiation exposure.

\section{Conclusion}

To conclude, ${ }^{18} \mathrm{~F}-\mathrm{FDG}$ PET/CT provides important information for the staging, restaging, response to treatment, and detection of metastatic disease, but it has limited contribution to early diagnosis in childhood tumors particularly in lymphoma, primary bone, and soft tissue tumors. It is a non-invasive imaging method that reflects both the metabolic features and the structural status of the tumors. As the preparation and image interpretation of the pediatric patients differ from adults, these procedures should be performed with specific information and experience on this age group. It should also be noted that indications of ${ }^{18} \mathrm{~F}-\mathrm{FDG}$ PET/CT must be considered appropriately since the exposure to radiation in children has more severe consequences than the adults.

\section{Ethics}

Ethics Committee Approval: The study was approved by the University of Health Sciences Turkey, Samsun Training and Research Hospital of Local Ethics Committee (protocol number: GOKA/2020/10/6).
Informed Consent: Consent form was filled out by all participants.

Peer-review: Externally peer-reviewed.

\section{Authorship Contributions}

Surgical and Medical Practices: N.B., M.E., Concept: N.B., Design: N.B., M.E., Data Collection or Processing: N.B., M.E., Analysis or Interpretation: N.B., Literature Search: N.B., Writing: N.B.

Conflict of Interest: No conflict of interest was declared by the authors.

Financial Disclosure: The authors declared that this study has received no financial support.

\section{References}

1. Voss SD. Pediatric oncology and the future of oncological imaging. Pediatr Radiol 2011;41:172-185.

2. Freebody J, Wegner EA, Rossleigh MA. 2-deoxy-2-((18)F) fluoro-Dglucose positron emission tomography/computed tomography imaging in paediatric oncology. World J Radiol 2014;6:741-755.

3. Costantini DL, Vali R, Chan J, McQuattie S, Charron M. Dual-time-point FDG PET/CT for the evaluation of pediatric tumors. AJR Am J Roentgenol 2013;200:408-413.

4. Shulkin BL. PET imaging in pediatric oncology. Pediatr Radiol 2004;34:199204

5. Uslu L, Donig J, Link M, Rosenberg J, Quon A, Daldrup-Link HE. Value of 18F-FDG PET and PET/CT for evaluation of pediatric malignancies. J Nuc Med 2015;56:274-286.

6. Cheng G, Servaes S, Zhuang H. Value of (18)F-fluoro-2-deoxy-D-glucose positron emission tomography/computed tomography scan versus diagnostic contrast computed tomography in initial staging of pediatric patients with lymphoma. Leuk Lymphoma 2013;54:737-742.

7. Miller E, Metser $U$, Avrahami G, Dvir R, Valdman D, Sira LB, Sayar D, Burstein Y, Toren A, Yaniv I, Even-Sapir E. Role of 18F-FDG PET/CT in staging and follow-up of lymphoma in pediatric and young adult patients. J Comput Assist Tomogr 2006;30:689-694.

8. Steliarova-Foucher E, Stiller C, Lacour B, Kaatsch P. International Classification of Childhood Cancer, third edition. Cancer 2005;103:14571467.

9. Percy $\mathrm{CL}$, Smith MA, Linet $\mathrm{M}$. Et al. Lymphomas and reticuloendothelia neoplasms.In: Ries LAG, Smith MA, Gurney, et al., eds. Cancer incidance and Survival Among children and adolescents: United States SEER Program 1975-1995. Bethesda MD: National Cancer Institude;1999. NIH publication 99-4649.

10. Amankwah EK, Conley AP, Reed DR. Epidemiology and therapies for metastatic sarcoma. Clin Epidemiol 2013;5:147-162.

11. Ducimetière $F$, Lurkin $A$, Ranchère-Vince $D$, Decouvelaere $A V$, Péoc'h $M$, Istier L, Chalabreysse P, Muller C, Alberti L, Bringuier PP, Scoazec JY, Schott AM, Bergeron C, Cellier D, Blay JY, Ray-Coquard I. Incidence of sarcoma histotypes and molecular subtypes in a prospective epidemiological study with central pathology review and molecular testing. PLoS One 2011;6:20294.

12. Arndt CA, Crist WM. Common musculoskeletal tumors of childhood and adolescence. N Engl J Med 1999;341:342-352.

13. Burns DK, Kumar V. The musculoskeletal system. In: Kumar V, Cotran RS, Robbins SL, eds. Robbins Basic Pathology. 7th ed. Philadelphia, Pennsylvania: Saunders; 2003:769-770.

14. Bhojwani D, McCarville MB, Choi JK, Sawyer J, Metzger ML, Inaba H, Davidoff AM, Gold R, Shulkin BL, Sandlund JT. The role of FDG-PET/CT in 
the evaluation of residual disease in paediatric non-Hodgkin lymphoma. Br J Haematol 2015;168:845-853.

15. Uslu-Beşli L, Atay Kapucu LÖ, Karadeniz C, Akdemir ÜÖ, Pinarli FG, Aydos U, Okur A, Kaya Z, Samanci C, Karabacak NI. Comparison of FDG PET/MRI and FDG PET/CT in Pediatric Oncology in Terms of Anatomic Correlation of FDG-positive Lesions. J Pediatr Hematol Oncol 2019;41:542-550.

16. American Academy of Pediatrics Committee on Drugs: Guidelines for monitoring and management of pediatric patients during and after sedation for diagnostic and therapeutic procedures. Pediatrics 1992;89:1110-1115.

17. American Society of Anesthesiologists Task Force on Sedation and Analgesia by Non-Anesthesiologists. Practice guidelines for sedation and analgesia by non-anesthesiologists. Anesthesiology 2002;96:1004-1017.

18. Cohade C, Mourtzikos KA, Wahl RL. "USA-Fat": prevalence is related to ambient outdoor temperature-evaluation with 18F-FDG PET/CT. J Nucl Med 2003;44:1267-1270.

19. Cohade C, Osman M, Pannu HK, Wahl RL. Uptake in supraclavicular area fat ("USA-Fat"): description on 18F-FDG PET/CT. J Nucl Med 2003;44:170-176.

20. Yeung HW, Grewal RK, Gonen M, Schöder H, Larson SM. Patterns of (18)F-FDG uptake in adipose tissue and muscle: a potential source of false-positives for PET. J Nucl Med 2003;44:1789-1796.

21. Steliarova-Foucher $E$, Colombet M, Ries LAG, Moreno F, Dolya A, Bray

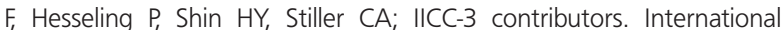
incidence of childhood cancer, 2001-10: a population-based registry study. Lancet Oncol 2017;18:719-731.

22. Nihayah S, Shammas A, Vali R, Parra D, Alexander S, Amaral J, Connolly B. Correlation of PET/CT and Image-Guided Biopsies of Pediatric Malignancies. AJR Am J Roentgenol 2017;208:656-662.

23. Dong $Y$, Zhang $X$, Wang $S$, Chen $S, M a$ C. 18F-FDG PET/CT is useful in initial staging, restaging for pediatric rhabdomyosarcoma. Q J Nucl Med Mol Imaging 2017;61:438-446.

24. Hurley C, McCarville MB, Shulkin BL, Mao S, Wu J, Navid F, Daw NC, Pappo AS, Bishop MW. Comparison of (18) F-FDG-PET-CT and Bone Scintigraphy for Evaluation of Osseous Metastases in Newly Diagnosed and Recurrent Osteosarcoma. Pediatr Blood Cancer 2016;63:13811386.

25. Treglia G, Taralli S, Bertagna F, Salsano M, Muoio B, Novellis P, Vita ML, Maggi F, Giordano A. Usefulness of whole-body fluorine-18fluorodeoxyglucose positron emission tomography in patients with neurofibromatosis type 1: a systematic review. Radiol Res Pract 2012;2012:431029.

26. London K, Cross S, Onikul E, Dalla-Pozza L, Howman-Giles R. 18F-FDG $\mathrm{PET} / \mathrm{CT}$ in paediatric lymphoma: comparison with conventional imaging. Eur J Nucl Med Mol Imaging 2011;38:274-284.

27. Kluge R, Kurch L, Georgi T, Metzger M. Current Role of FDG-PET in Pediatric Hodgkin's Lymphoma. Semin Nucl Med 2017;47:242-257.

28. Flerlage JE, Kelly KM, Beishuizen A, Cho S, De Alarcon PA, Dieckmann U, Drachtman RA, Hoppe BS, Howard SC, Kaste SC, Kluge R, Kurch L, Landman-Parker J, Lewis J, Link MP, McCarten K, Punnett A, Stoevesandt D, Voss SD, Wallace WH, Mauz-Körholz C, Metzger ML. Staging Evaluation and Response Criteria Harmonization (SEARCH) for Childhood, Adolescent and Young Adult Hodgkin Lymphoma (CAYAHL): Methodology statement. Pediatr Blood Cancer 2017;64.

29. Gatenby RA, Gillies RJ. Why do cancers have high aerobic glycolysis? Nat Rev Cancer 2004;4:891-899.

30. Portwine C, Marriott C, Barr RD. PET imaging for pediatric oncology: an assessment of the evidence. Pediatr Blood Cancer 2010;55:1048-1061.

31. McCarville MB. PET-CT imaging in pediatric oncology. Cancer Imaging 2009;9:35-43

32. Franzius C. FDG-PET/CT in pediatric solid tumors. Q I Nucl Med Mol Imaging 2010;54:401-410
33. Kleis M, Daldrup-Link H, Matthay K, Goldsby R, Lu Y, Schuster T, Schreck C, Chu PW, Hawkins RA, Franc BL. Diagnostic value of PET/CT for the staging and restaging of pediatric tumors. Eur J Nucl Med Mol Imaging 2009:36:23-36.

34. Furth C, Steffen IG, Amthauer H, Ruf J, Misch D, Schönberger S, Kobe C, Denecke T, Stöver B, Hautzel H, Henze G, Hundsdoerfer P. Early and late therapy response assessment with [18F] fluorodeoxyglucose positron emission tomography in pediatric Hodgkin's lymphoma: analysis of a prospective multicenter trial. J Clin Oncol 2009;27:4385-4391.

35. Gallamini A, Hutchings $M$, Avigdor A, Polliack A. Early interim PET scan in Hodgkin lymphoma: where do we stand? Leuk Lymphoma 2008;49:659-662.

36. Hawkins DS, Conrad EU 3rd, Butrynski JE, Schuetze SM, Eary JF. [F-18]fluorodeoxy-D-glucose-positron emission tomography response is associated with outcome for extremity osteosarcoma in children and young adults. Cancer 2009;115:3519-3525.

37. Hawkins DS, Schuetze SM, Butrynski JE, Rajendran JG, Vernon $C B$, Conrad EU 3rd, Eary JF. [18F]Fluorodeoxyglucose positron emission tomography predicts outcome for Ewing sarcoma family of tumors. J Clin Oncol 2005;23:8828-8834.

38. Gelfand MJ, Parisi MT, Treves ST; Pediatric Nuclear Medicine Dose Reduction Workgroup. Pediatric radiopharmaceutical administered doses: 2010 North American consensus guidelines. J Nucl Med 2011;52:318-322

39. Treves ST, Gelfand MJ, Fahey FH, Parisi MT. 2016 Update of the North American Consensus Guidelines for Pediatric Administered Radiopharmaceutical Activities. J Nucl Med 2016;57:15-18.

40. Qiu L, Chen Y, Wu J. The role of 18F-FDG PET and 18F-FDG PET/CT in the evaluation of pediatric Hodgkin's lymphoma and non-Hodgkin's lymphoma. Hell J Nucl Med 2013;16:230-236.

41. London K, Cross S, Onikul E, Dalla-Pozza L, Howman-Giles R. 18F-FDG $\mathrm{PET} / \mathrm{CT}$ in paediatric lymphoma: comparison with conventional imaging. Eur J Nucl Med Mol Imaging 2011;38:274-284.

42. Sharp SE, Gelfand MJ, Shulkin BL. Pediatrics: diagnosis of neuroblastoma. Semin Nucl Med 2011;41:345-353.

43. Piccardo A, Lopci E, Conte M, Foppiani L, Garaventa A, Cabria M, Villavecchia G, Fanti S, Cistaro A. PET/CT imaging in neuroblastoma. Q J Nucl Med Mol Imaging 2013;57:29-39.

44. Mueller WP, Coppenrath E, Pfluger T. Nuclear medicine and multimodality imaging of pediatric neuroblastoma. Pediatr Radiol 2013;43:418-427.

45. Kushner BH, Yeung HW, Larson SM, Kramer K, Cheung NK. Extending positron emission tomography scan utility to high-risk neuroblastoma: fluorine-18 fluorodeoxyglucose positron emission tomography as sole imaging modality in follow-up of patients. J Clin Oncol 2001;19:33973405.

46. Choi YJ, Hwang HS, Kim HJ, Jeong YH, Cho A, Lee JH, Yun M, Lee JD, Kang WJ. (18)F-FDG PET as a single imaging modality in pediatric neuroblastoma: comparison with abdomen $\mathrm{CT}$ and bone scintigraphy. Ann Nucl Med 2014;28:304-313.

47. Alexander N, Vali R, Ahmadzadehfar H, Shammas A, Baruchel S. Review: The Role of Radiolabeled DOTA-Conjugated Peptides for Imaging and Treatment of Childhood Neuroblastoma. Curr Radiopharm 2018;11:1421

48. Bodei L, Cremonesi M, Grana CM, Fazio N, lodice S, Baio SM, Bartolomei M, Lombardo D, Ferrari ME, Sansovini M, Chinol M, Paganelli G. Peptide receptor radionuclide therapy with ${ }^{177}$ Lu-DOTATATE: the IEO phase I-II study. Eur J Nucl Med Mol Imaging 2011;38:2125-2135.

49. Bodei L, Mueller-Brand J, Baum RP, Pavel ME, Hörsch D, O'Dorisio MS, O'Dorisio TM, Howe JR, Cremonesi M, Kwekkeboom DJ, Zaknun JJ. The joint IAEA, EANM, and SNMMI practical guidance on peptide receptor radionuclide therapy (PRRNT) in neuroendocrine tumours. Eur J Nucl Med Mol Imaging 2013;40:800-816 
50. Brans B, Mottaghy FM, Kessels A. 90Y/177Lu-DOTATATE therapy: survival of the fittest? Eur J Nucl Med Mol Imaging 2011;38:1785-1787.

51. Delpassand ES, Samarghandi A, Zamanian S, Wolin EM, Hamiditabar M, Espenan GD, Erion JL, O'Dorisio TM, Kvols LK, Simon J, Wolfangel R, Camp A, Krenning EP, Mojtahedi A. Peptide receptor radionuclide therapy with 177Lu-DOTATATE for patients with somatostatin receptorexpressing neuroendocrine tumors: the first US phase 2 experience. Pancreas 2014;43:518-525.

52. Kunikowska J, Królicki L, Hubalewska-Dydejczyk A, Mikołajczak R, Sowa-Staszczak A, Pawlak D. Clinical results of radionuclide therapy of neuroendocrine tumours with 90Y-DOTATATE and tandem 90Y/177LuDOTATATE: which is a better therapy option? Eur J Nucl Med Mol Imaging 2011;38:1788-1797.

53. Maecke HR, Reubi JC. Somatostatin receptors as targets for nuclear medicine imaging and radionuclide treatment. J Nucl Med 2011;52:841844.

54. Waldherr C, Pless M, Maecke HR, Haldemann A, Mueller-Brand J. The clinical value of [90Y-DOTA]-D-Phe1-Tyr3-octreotide (90Y-DOTATOC) in the treatment of neuroendocrine tumours: a clinical phase II study. Ann Oncol 2001;12:941-945.

55. Kong G, Hofman MS, Murray WK, Wilson S, Wood P, Downie P, Super L, Hogg A, Eu P, Hicks RJ. Initial Experience With Gallium-68 DOTAOctreotate PET/CT and Peptide Receptor Radionuclide Therapy for Pediatric Patients With Refractory Metastatic Neuroblastoma. J Pediatr Hematol Oncol 2016;38:87-96.

56. Gains JE, Bomanji JB, Fersht NL, Sullivan T, D'Souza D, Sullivan KP, Aldridge M, Waddington W, Gaze MN. 177Lu-DOTATATE molecular radiotherapy for childhood neuroblastoma. J Nucl Med 2011;52:1041-1047.

57. Menda Y, O'Dorisio MS, Kao S, Khanna G, Michael S, Connolly M, Babich J, O'Dorisio T, Bushnell D, Madsen M. Phase I trial of 90Y-DOTATOC therapy in children and young adults with refractory solid tumors that express somatostatin receptors. J Nucl Med 2010;51:1524-1531.
58. Sadowski SM, Neychev V, Millo C, Shih J, Nilubol N, Herscovitch P, Pacak K, Marx SJ, Kebebew E. Prospective Study of 68Ga-DOTATATE Positron Emission Tomography/Computed Tomography for Detecting GastroEntero-Pancreatic Neuroendocrine Tumors and Unknown Primary Sites. J Clin Oncol 2016;34:588-596.

59. Ludwig JA. Ewing sarcoma: historical perspectives, current state-ofthe-art, and opportunities for targeted therapy in the future. Curr Opin Oncol 2008;20:412-418

60. Bestic JM, Peterson JJ, Bancroft LW. Pediatric FDG PET/CT: Physiologic uptake, normal variants, and benign conditions [corrected]. Radiographics 2009;29:1487-1500

61. Hartley AL, Birch JM, Blair V, Kelsey AM, Harris M, Jones PH. Patterns of cancer in the families of children with soft tissue sarcoma. Cancer 1993;72:923-930.

62. Eugene T, Corradini N, Carlier T, Dupas B, Leux C, Bodet-Milin C. 18F-FDG-PET/CT in initial staging and assessment of early response to chemotherapy of pediatric rhabdomyosarcomas. Nucl Med Commun 2012;33:1089-1095.

63. Schäfer JF, Gatidis S, Schmidt H, Gückel B, Bezrukov I, Pfannenberg CA, Reimold $M$, Ebinger $M$, Fuchs J, Claussen CD, Schwenzer NF. Simultaneous whole-body PET/MR imaging in comparison to PET/CT in pediatric oncology: initial results. Radiology 2014;273:220-231.

64. Rausch I, Quick HH, Cal-Gonzalez J, Sattler B, Boellaard R, Beyer T. Technical and instrumentational foundations of PET/MRI. Eur J Radiol 2017;94:3-13.

65. Qi Z, Gates EL, O'Brien MM, Trout AT. Radiation dose reduction through combining positron emission tomography/computed tomography (PET/ CT) and diagnostic CT in children and young adults with lymphoma. Pediatr Radiol 2018;48:196-203. 